\title{
4 Why Public Reasoning Involves Ideal Theorizing
}

\author{
BLAIN NEUFELD
}

A NUMBER OF CONTEMPORARY POLITICAL PHILOSOPHERS-including Elizabeth Anderson, Gerald Gaus, and Amartya Sen ${ }^{1}$ - endorse versions of "public reason" as the appropriate way to justify fundamental political decisions within pluralist democratic societies, while rejecting "ideal theory." I contend that these ideas are not easily separated. Public reasoning unavoidably entails what I call "local ideal theorizing." In local ideal theorizing, political proposals are justified, at least in part, through consideration and evaluation of those proposals under conditions of compliance with them by the citizens to whom those justifications are addressed. Local ideal theorizing, moreover, naturally leads to "full ideal theorizing." When citizens engage in full ideal theorizing, they outline an amended version of their society's "basic structure," ${ }^{3}$ a version that includes the various political proposals that they take to be required by justice, under conditions of general compliance.

Why do public reason justifications for political proposals involve ideal theorizing? The idea of public reason expresses a form of mutual "civic" respect for persons as free and equal citizens. Hence public reason justifications

\footnotetext{
${ }^{1}$ See Anderson 1999, 2009, 2010; Gaus 2010, 2011; Gaus and Vallier 2009; and Sen 2009. (On the inclusion of Anderson, see my discussion at the end of the second section.)

${ }^{2}$ The version of ideal theory that I focus on is that of John Rawls. For Rawls's explanation of "ideal" and "non-ideal" theory, "partial compliance," and "strict compliance" theory, and the ideas of a "well-ordered society" and a "realistic utopia," see Rawls 1999, 4-5, 7-8, 215-16, 308-9; 2001, $4-5,13,65-66$. The main assumptions of Rawlsian ideal theory are "strict compliance" and "favourable circumstances" (see Rawls 1999, 216; 2001, 101). I do not discuss the second assumption here. ${ }^{3}$ The "basic structure," roughly, consists of the main institutions of society understood as an overall system of social cooperation. These institutions apply to all citizens within society, unlike "voluntary associations," such as religious organizations, firms, unions, clubs, and universities. (See Rawls 2001, §4; 2005, Lecture VII. For the interpretation of the basic structure that I favor, see Neufeld and Van Schoelandt 2014.)
} 
for political proposals are addressed to citizens capable of accepting those justifications-and in virtue of that acceptance, complying (ceteris paribus) with the demands of their society's basic structure following its revision in accordance with those proposals. In aiming at citizens' acceptance, and thereby compliance, public reason justifications for proposals must take into account what the basic structure of citizens' society would look like should it be revised to include those proposals, including with those citizens' acceptance and compliance. Thus public reason justifications for particular political proposals involve local ideal theorizing. And the activity of engaging in local ideal theorizing generates pressure on public reasoners to engage in full ideal theorizing, to consider what their society would look like if all of the main political proposals that they think are required by justice were implemented and complied with by their fellow citizens.

The view that I develop here differs from what I take to be the standard account of the relation between public reasoning and ideal theorizing. According to the standard account, roughly, citizens should first work out or identify a political conception of justice at the level of full ideal theory, ${ }^{4}$ and then draw upon this conception when making public reason arguments for or against particular political proposals in non-ideal circumstances. The ideal of a fully just society provides citizens with an exemplar for thinking critically about their own society, and a target for their proposed political reforms. ${ }^{5}$

I do not defend - but do not reject - this way of understanding the relation between public reason and ideal theory here. Instead, I explain that even if public reasoners begin with political deliberation in non-ideal circumstancesindeed, even if they initially attempt to eschew any role for ideal theorizing in their public reasoning - the nature of public reasoning itself compels public reasoners to engage in at least local ideal theorizing. And local ideal theorizing leads naturally, though perhaps not inevitably, to full ideal theorizing. Thus the direction of the relation between ideal and non-ideal theory in my account is the reverse of that found within the standard account: the ideal theorizing that public reasoners engage in emerges out of critical reflection and deliberation concerning the non-ideal political circumstances within which they find themselves. The upshot of my argument, then, is that irrespective of whether one thinks that political philosophy should focus primarily on addressing specific injustices, or instead on identifying first what "full justice" requires, a commitment to public reason justifications entails a role for ideal theory as part of those justifications. ${ }^{6}$

\footnotetext{
${ }^{4}$ Ideal theory is not sufficient for identifying the most reasonable conception of justice. The "original position" device, which makes use of ideal theory (see n. 15), serves this function (see Rawls 2001, $\S \S 6,23-40)$.

${ }^{5}$ See Simmons 2010; Stemplowska and Swift 2014; Valentini 2012.

${ }^{6}$ Thanks to an anonymous referee for recommending that I clarify this point.
} 
My discussion proceeds as follows. In the first section I outline the main elements of John Rawls's account of public reason, as well as the standard view of the relation between ideal theory and public reason. In the second section I explain what I take to be the relations between public reason justifications for political proposals (broadly construed ${ }^{7}$ ), citizens' acceptance of those justifications, citizens' compliance (ceteris paribus) with those proposals (should they be implemented), and public reasoners' reflection and deliberation concerning the overall coherence of their main political proposals. In the third section I attempt to clarify the account outlined in the second section by sketching how full ideal theorizing can emerge out of reflection upon the political and economic injustices of the contemporary United States. According to the account that I present in the second and third sections, roughly, public reasoning within non-ideal circumstances can move citizens from addressing pressing political injustices to engaging in ideal theorizing — and back again.

"Public reason" is the name that Rawls gives to the shared form of reasoning that the citizens of a liberal democratic society characterized by "reasonable pluralism" should use when deciding "constitutional essentials" and "matters of basic justice." Indeed, he holds that public reason should be understood as "part of the idea of democracy itself." 10 The terms of public reason are provided by the family of reasonable political conceptions of justice endorsed by citizens. ${ }^{11}$ All reasonable political conceptions of justice are committed to "the underlying ideas of citizens as free and equal persons and society as a fair system of cooperation over time." ${ }^{12}$ Reasonable political conceptions of justice,

\footnotetext{
${ }^{7}$ See n. 34 .

${ }^{8}$ According to the "fact of reasonable pluralism," roughly, citizens invariably will come to endorse a variety of different "comprehensive doctrines" (religious, moral, and/or philosophical views, such as utilitarianism and Buddhism) through the free exercise of their reason (Rawls 2005, 441).

${ }^{9}$ See Rawls 2005, 214-15, 227-30, 235. For the purposes of this paper, I follow Rawls in holding that public reason justifications apply primarily to questions regarding constitutional essentials and matters of basic justice.

${ }^{10}$ Rawls 2005, 441.

${ }^{11}$ A "reasonable" conception of justice possesses three features (Rawls 2005, 450). First, it secures equally for all citizens a set of "basic liberties." Second, it assigns to the basic liberties a "special priority" vis-à-vis other political principles and values (e.g., overall welfare). Third, it assures for all citizens adequate resources for them to exercise effectively the basic liberties over the course of their lives. A conception of justice is "political" (as opposed to "comprehensive") if it is characterized by three further features (Rawls 2005, 453). First, it satisfies the "basic structure restriction," that is, it is limited in its scope to the main political and economic institutions of society. Second, it fulfills the "freestanding condition": the ideas it employs are compatible with the various comprehensive doctrines endorsed by reasonable citizens. Third, it draws upon ideas central to the public political culture of democratic society, such as the idea of free and equal citizenship.

${ }^{12}$ Rawls 2005, 450-51.
} 
then, are interpretations and specifications of these fundamental liberal democratic ideas. (And while there is a family of reasonable political conceptions, Rawls claims that "justice as fairness" is the most reasonable one. ${ }^{13}$ )

A reasonable political conception of justice, according to Rawls, initially should be formulated and evaluated as a conception that organizes the basic structure of a "well-ordered society." The citizens of a well-ordered society are understood as "reasonable persons." ${ }^{14}$ Such citizens freely and consistently support the institutions of their basic structure..$^{15}$ Consequently, a well-ordered society is "stable for the right reasons." ${ }^{16}$ Rawls describes a well-ordered society as a "realistic utopia." It is "realistic" in taking certain natural, social, and psychological facts as given, but "utopian" in imagining what, given these facts, a fully legitimate and just society would look like. A central purpose of the idea of the realistic utopia of a well-ordered society is to explore the limits of what is politically possible with respect to justice. ${ }^{17}$

According to the standard Rawlsian account of the relation between public reason and ideal theory, public reason justifications draw upon reasonable political conceptions of justice, and such conceptions are formulated at the level of full ideal theory, that is, through consideration of their full realization within the realistic utopia of a well-ordered society. There seems to be, however, no necessary connection between ideal theory and public reason on this account. This perhaps should not be surprising, as Rawls's conception of a

\footnotetext{
${ }^{13}$ Rawls 2005, xlvi.

${ }^{14}$ Two features characterize "reasonable persons" within Rawlsian political liberalism: (1) acknowledgement of the fact of reasonable pluralism, and (2) endorsement of the "criterion of reciprocity" (see Rawls 2005, 48-58). Within non-well-ordered (but broadly liberal) societies, most citizens have the capacity to be reasonable persons, even if they presently are not. (The idea of reasonable persons within political liberalism does not correspond to the notion of "reasonableness" as it is used in everyday discourse. Moreover, it may be the case that [some or many] unreasonable persons can accept particular public reason justifications for political proposals. Such unreasonable persons, though, do not think that it is necessary that political proposals regarding constitutional essentials and matters of basic justice be justified via public reason.) I leave further discussion of the issues posed by unreasonable citizens for another time.

${ }^{15}$ Strict compliance is assumed only within the first stage of the original position, specifically, the stage at which the parties initially select which conception of justice should govern the basic structure of the society in which the citizens whom they represent will live out their lives. The second stage of the original position involves determining whether a fully just well-ordered society-a society with a basic structure that is organized in accordance with the conception of justice selected at the first stage - would be stable over time for the right reasons, namely, through the free compliance of its reasonable citizens (see Rawls 2001, §§54-55). Here compliance is not assumed. Rather, it must be shown that citizens raised within such a society will acquire an effective "sense of justice" (see n. 21), and, moreover, will regard their sense of justice as appropriately regulative of their behavior over time. Consequently, there are, so to speak, two levels of idealization within Rawls's overall argument for justice as fairness. In the first stage of the original position, strict compliance is assumed by the parties; within the second stage, compliance is not assumed, but must be shown to be justified despite (inter alia) the fact of reasonable pluralism.

${ }^{16}$ Rawls 2005, 390-92, 459.

${ }^{17}$ Rawls 2005, 4-5.
}

76 Political Utopias 
well-ordered society and his use of ideal theory predate his introduction of the idea of public reason. ${ }^{18}$ But before I turn to the relation between ideal theory and public reason, I would like to dispel a misunderstanding of what ideal theory's compliance assumption involves.

Some critics of ideal theory's compliance assumption charge it with employing an unrealistic account of human behavior. Anderson, for instance, explains her rejection of ideal theory's full compliance assumption in the following way: "A system of principles that would produce a just world if they regulated the conduct of perfectly rational and just persons will not do so when we ask human beings, with all our limitations and flaws, to follow them." 19 In a similar vein, Sen complains that Rawls, in formulating his conception of justice as fairness, makes "forceful use of the sweeping assumption of compliance with a specific kind of 'reasonable' behaviour by all." ${ }^{20}$ This assumption is too unrealistic, according to Sen, to be helpful for actual citizens' deliberations over how to promote justice or ameliorate injustice in their existing societies. These criticisms hold that full compliance requires quite a lot of citizens, more than we can expect realistically of most human beings.

I think that this line of criticism is misguided, as compliance for Rawls must be feasible for most persons. It is the case that Rawls's understanding of the nature of citizens' compliance with the requirements of justice within a well-ordered society requires that most citizens' "sense of justice" be effective, that is, that it move them adequately to comply consistently with the laws and institutions of their just basic structure. ${ }^{21}$ But citizens brought up within a well-ordered society naturally will acquire and rationally retain an effective sense of justice. ${ }^{22}$ And in positing general compliance on the part of the citizens of a well-ordered society, Rawls holds that it is vital to take into account considerations of human psychology. Compliance with the requirements of justice must be feasible for most human beings, not simply "perfectly rational and just persons." "The general facts of human psychology and the principles of moral learning are relevant matters," Rawls writes. ${ }^{23}$ Thus the demands on citizens imposed by a conception of justice must be ones that flesh-andblood human beings can accept, and with which they can comply adequately

${ }^{18}$ Given that the fact of reasonable pluralism applies to a well-ordered society-something that Rawls did not address in A Theory of Justice-public reasoning may play a role in assuring the citizens of such a society of the compliance of other citizens. (See Weithman [2010] on the role of public reason in overcoming the "assurance problem" faced by citizens within a well-ordered society.) While public reason might have a role to play within ideal theory, though, ideal theory may have no necessary role to play within public reason.

${ }^{19}$ Anderson 2010, 3-4 (my italics).

${ }^{20}$ Sen 2009, 90; see also 68-69, 79-81.

${ }^{21}$ The "sense of justice" is part of citizens' reasonable nature (see Rawls 2001, 196).

${ }^{22}$ See Rawls 1999, part III.

${ }^{23}$ Rawls 1999, 125. 
to maintain their society's just basic structure over time. If this is not the case, then Rawls holds that that fact alone is sufficient warrant for rejecting that conception of justice. ${ }^{24}$ This requirement sometimes is expressed in terms of what Rawls calls the "strains of commitment." ${ }^{25}$ According to this requirement, roughly, compliance with what justice requires cannot impose intolerable "strains" on citizens; that is, whatever their position in society, compliance with the laws and institutions of their basic structure cannot require citizens to sacrifice or jeopardize their fundamental interests, ${ }^{26}$ or even to allow them to become unduly estranged from their political society. ${ }^{27}$

Why engage in ideal theorizing, according to the standard account? By identifying the limits of what is politically possible for citizens who also are human beings, one role of the realistic utopia of a well-ordered society is to serve as an institutional ideal toward which citizens in existing political societies can and should strive in reforming their basic structures. Rawls writes, "[T] he idea of a well-ordered society should ... provide some guidance in thinking about nonideal theory, and so about difficult cases of how to deal with existing injustices. It should also help clarify the goal of reform and to identify which wrongs are more grievous and hence more urgent to correct." ${ }^{28}$ The basic structure of a wellordered society, then, constitutes a just end-state toward which citizens' reforms ultimately should aim, as well as providing the citizens of a non-well-ordered society with a tool for identifying which of the unjust elements of their society's basic structure are the most serious, thereby facilitating priority setting. ${ }^{29}$ And the role of the full compliance assumption is to help ensure that the specification of what a fully just society requires is not unjustifiably compromised by accommodating or "watering down" principles of justice in light of possible unreasonable non-compliance by some or many citizens. ${ }^{30}$

\footnotetext{
${ }^{24}$ Specifically, it is sufficient warrant for the parties within the second stage of the original position to reject that conception. (On the two stages of the original position, see n. 15.)

${ }^{25}$ See Rawls 1999, 126, 153-54; 2001, 103-4, 110, 128-29.

${ }^{26}$ The adequate exercise of the two "moral powers"-namely, citizens' capacities for a conception of the good and a sense of justice (Rawls 2001, 18-19) — over the course of their lives make up citizens' "higher-order interests" (Rawls 2001, 74-75, 106).

${ }^{27}$ More precisely, a less severe way in which the strains of commitment can become "excessive" than requiring citizens to sacrifice their fundamental interests, is that the principles of justice that are realized in the basic structure have the effect of leading citizens to "grow distant from political society." In this case, citizens "feel left out," and consequently "cannot affirm the principles of justice in ... [their] ... thought and conduct over a complete life" (Rawls 2001, 128). Capitalist societies tend to engender this form of alienation among many citizens, according to Rawls.

${ }^{28}$ Rawls 2005, 13.

${ }^{29}$ For instance, since a society with a basic structure organized in compliance with the principles of Rawls's conception of justice as fairness would uphold the lexical priority of the basic liberties, the citizens of non-well-ordered societies should prioritize addressing violations or inadequate protections of the basic liberties within their basic structures over other forms of injustice. (For some worries about the "priority setting" function of ideal theory, however, see Stemplowska and Swift 2014.) ${ }^{30}$ See nn. 4 and 15.
} 
Might public reason justifications for political proposals be severed entirely from the idea of a realistic utopia? According to the standard view of the relation between ideal theory and public reason justifications, the terms of public reason are drawn from reasonable political conceptions of justice, and such conceptions are formulated (at least in part) by reflection on their full realization within well-ordered societies. ${ }^{31}$ But, as noted earlier, this relation looks like it can be dropped. What seems essential to the idea of public reason is what Rawls calls the "criterion of reciprocity," roughly, the idea that the justifications for fundamental political decisions should be acceptable to the reasonable citizens subject to those decisions. ${ }^{32}$ Perhaps the criterion of reciprocity, and thus public reason justifications, can be deployed without any role for ideal theory, including its assumption of citizens' full compliance. As noted at the beginning of this paper, something like this view is endorsed by a number of prominent contemporary political philosophers. ${ }^{33}$

In this section I explain why public reason justifications for political proposals involve at least local ideal theorizing, that is, consideration of those proposals under conditions of general compliance on the part of the citizens to whom those justifications are addressed. ${ }^{34}$ Simply put, I hold that if one is committed to public reason justifications, then one must be committed to a role for (at least) local ideal theory as part of those justifications. ${ }^{35}$ I then explain why engaging in local ideal theorizing naturally will lead some citizens to engage in full ideal theorizing, that is, theorizing about a realistically utopian version of their society. The move from local to full ideal theorizing makes sense for

\footnotetext{
${ }^{31}$ Given Rawls's focus on outlining the main features of a well-ordered society, and his discussion of the role of public reason in maintaining the stability of such a society, one might conclude that Rawls holds that citizens have a duty to justify their political decisions in terms of public reason only within a well-ordered society. Such an interpretation would be mistaken, though, as Rawls holds that public reason justifications should be available, at least eventually, for fundamental political decisions even within unjust societies. See, for instance, his discussion of the American abolitionist and civil rights movements (Rawls 2005, 249-51). Rawls's proposals for addressing what he takes to be the main injustices of the American political and economic system of his own time are formulated in terms of public reason (I mention some of these proposals in the third section). For further discussion of the role of public reason in non-ideal circumstances, see Hadfield and Macedo 2012.

${ }^{32}$ See Rawls 2005, 446-47, xliv-xlv.

${ }^{33}$ See n. 1.

${ }^{34}$ In this section, I use the term "public reason justifications" to refer to all justifications for political proposals that aim to satisfy the criterion of reciprocity. Such justifications need not draw upon complete reasonable political conceptions of justice. Indeed, one of my goals in this section is to show why citizens may want to identify or work out a complete political conception of justice as a result of their reflection upon the various specific political proposals that they endorse in non-ideal circumstances.

${ }^{35}$ I take a commitment to public reason justifications for granted in my discussion here.
} 
those citizens who are concerned about the overall coherence of the political proposals that they endorse.

Rawls's criterion of reciprocity underpins his idea of public reason. ${ }^{36}$ Indeed, the criterion of reciprocity (or some principle very similar to it) underpins all leading contemporary accounts of public reasoning, including those accounts that differ in other respects from Rawls's. ${ }^{37}$ According to the criterion of reciprocity, Rawls writes, "our exercise of political power is proper only when we sincerely believe that the reasons we would offer for our political actions may reasonably be accepted by other citizens as a justification of those actions." ${ }^{38}$ Political decisions that are supported adequately by public reason justifications satisfy the criterion of reciprocity, and consequently have normative authority for citizens. ${ }^{39}$ This is because, by satisfying the criterion of reciprocity, the justifications for those political decisions are acceptable to all reasonable citizens, even though they adhere to different comprehensive doctrines. Reasonable citizens may disagree over which laws and institutions are the best or most just ones for their society, and thus may assess differently the strength of different public reason justifications. As Rawls remarks, "[U]nanimity of views is not to be expected." ${ }^{40}$ What is essential, though, is that public reason justifications at least be acceptable to reasonable citizens.

By aiming to satisfy the criterion of reciprocity when justifying political proposals, citizens express mutual respect for one another. More precisely, they conform to what I call the "principle of equal civic respect." ${ }^{41}$ Civic respect is a form of what Stephen Darwall terms "recognition respect." 42 Recognition respect, roughly, is the kind of respect that is owed to persons in virtue of some characteristic that they possess; this characteristic grants such persons a certain standing in their relations with others. Civic respect is a form

${ }^{36}$ The criterion of reciprocity also grounds the "liberal principle of legitimacy" (Rawls 2005, xliv, 137, 446-47). Indeed, the criterion of reciprocity expresses the "intrinsic (moral) political ideal" of political liberalism (Rawls 2005, xlv). It is because the criterion of reciprocity occupies this basic normative role in political liberalism that Rawls asserts that while there may exist "a family of reasonable political conceptions" of justice, "[t]he limiting feature of these forms is the criterion of reciprocity" $(2005,450)$.

${ }^{37}$ I mention Anderson's version of the criterion of reciprocity at the end of this section. Gaus's version of public reasoning is discussed at the end of the third section.

${ }^{38}$ Rawls 2005, xliv (my italics).

${ }^{39}$ Rawls 2005, 19.

${ }^{40}$ Rawls 2005, 479.

${ }^{41}$ A more extensive discussion of the principle of equal civic respect can be found in Neufeld 2005, $\S I I$. For the more general claim that the idea that public reason expresses a form of "respect for persons," see Boettcher 2007; Larmore 1999; Nussbaum 2011.

${ }^{42}$ On the idea of "recognition respect," see Darwall 1995, 2006, ch.6. A different kind of respect, what Darwall calls "appraisal respect," "consists in a positive appraisal of a person or his qualities.... Appraisal respect is the positive appraisal itself" " $(1995,184)$. Appraisal respect can be distinguished from recognition respect in that we might think that equal recognition respect is owed to persons for whom we have widely varying degrees of appraisal respect.

80 $\mid$ Political Utopias 
of recognition respect that is owed to persons in virtue of their standing as free and equal citizens. ${ }^{43}$ One expresses such respect by taking this standing into account when deciding fundamental political questions. And taking one's fellow citizens' free and equal standing into account when deciding fundamental political questions is understood, within political liberalism, to involve justifying those decisions on mutually acceptable grounds, that is, in providing justifications that satisfy the criterion of reciprocity.

When citizens give public reason justifications for their political proposals, then, they necessarily are committed to the acceptability of those justifications for other citizens-indeed, this simply is what satisfying the criterion of reciprocity involves. But what is the connection between the acceptability of a justification for, say, a law, and compliance with that law? In finding a justification for a law acceptable, I propose, citizens are willing, ceteris paribus, to comply freely with that law, that is, citizens acknowledge the normative authority of that law for their behavior. ${ }^{44}$ (Or at least, as I shall explain shortly, citizens who accept the justification for a law are willing to impose upon themselves the necessary arrangements to ensure their compliance with that law.) This is what it is for a citizen to be "reasonable," specifically, to be motivated by reciprocity in one's political relations with others. One reason for citizens to advance justifications for laws that satisfy the criterion of reciprocity is to bring about compliance with those laws in a manner compatible with citizens' political autonomy, namely, through the deliberative agency of the citizens in question. ${ }^{45}$ In doing so, citizens satisfy the principle of equal civic respect in their mutual relations.

When citizens advance a political proposal for their society's basic structure, part of the process of justifying that proposal is indicating what their basic structure would look like should that proposal be implemented. The hope is that other citizens will find the picture of the revised basic structure to be attractive, and thereby come to support freely the political proposal in question. In other words, part of a public reason justification for a political proposal is the portrayal of a shared social world in which that proposal, through the endorsement or acceptance of other reasonable citizens, is realized. Thus

\footnotetext{
${ }^{43}$ Because of its restriction to the basic structure and its "freestanding" character, civic respect can be distinguished from other, more "comprehensive" forms of recognition respect, such as that required by Kant's "Formula of Humanity."

${ }^{44}$ My claim here concerns the way in which public reason justifications are meant to function in citizens' deliberations about fundamental political issues. I do not mean to presuppose anything controversial about the nature of "reasons" per se (say, some form or "reasons" or "judgement" "internalism").

${ }^{45}$ Or at least to enable compliance via deliberative agency; compliance often simply is a matter of habit or deference to authority. What is important is that such compliance could be justified or, if necessary, be brought about via rational reflection by citizens. (Thanks to Julian Culp for discussion of this point.)
} 
a public reason justification for a particular political proposal involves local ideal theorizing, namely, consideration of an amended basic structure following reasonable citizens' acceptance of, and consequent compliance with, the political proposal in question.

I should note here that finding a justification for a political proposal convincing, and consequently endorsing that proposal as the most just or best proposal for one's society, differs from finding a proposal and its justification acceptable. A citizen finds a proposal "acceptable" insofar as she can appreciate the justification for the proposal, and willingly abide by its requirements should it be implemented democratically in her society's basic structure, even if she would prefer a different proposal, that is, even if she regards an alternative proposal as more just or better overall. ${ }^{46}$ (Recall Rawls's observation that, with respect to political decision-making by means of public reasoning, "unanimity of views is not to be expected." ${ }^{47}$ ) In order to implement democratically a political proposal, at least normally, citizens must convince enough other citizens to endorse it, that is, to regard it as the right or best proposal, at least among the available options, for their common political life. ${ }^{48}$ Should that proposal become law, it then governs legitimately those citizens who find the law and its justification "merely" acceptable. Such citizens, despite preferring a different law, and hence not endorsing the law in question, nonetheless recognize that law's normative authority for their conduct. ${ }^{49}$

Furthermore, it may be that finding acceptable or even endorsing a public reason justification for a law or institution is not always sufficient to bring about adequate compliance over time on the part of citizens with that law or institution. This especially may be the case within non-ideal circumstances. Many citizens, for instance, may be subject to foreseeable akrasia even with respect

\footnotetext{
${ }^{46}$ Unlike particular political proposals, or even complete conceptions of political justice, all reasonable citizens endorse the principle of civic respect, including the criterion of reciprocity. Indeed, such endorsement is a constitutive element of persons' reasonableness (see n. 14). (Thanks to Julian Culp for pressing me to clarify this point.)

${ }^{47}$ See n. 40.

${ }^{48}$ I should mention that my position is compatible with a law being passed that in fact no reasonable citizens endorse, but which all find acceptable (say, by means of a vote employing a Borda count method, in which no citizen's "first choice" ultimately succeeds). There also may exist laws that no reasonable citizens today endorse (as, for instance, they were passed long ago, or never were legislated formally, but are part of that country's system of common law), but which all citizens nonetheless find acceptable. (Thanks to Chad Van Schoelandt for helpful discussion of this point.)

${ }^{49}$ Insofar as all reasonable citizens endorse the principle of equal civic respect (n. 46), they may be understood as, in a sense, indirectly endorsing political decisions that comply with that principle. My reason for distinguishing between citizens" "acceptance" and "endorsement" of a political proposal is to indicate that citizens need not come to regard that proposal as the best or most just one, even following public political deliberation and voting concerning it. Such citizens may reasonably try to promote a different political proposal, while nonetheless recognizing the legitimacy of - and consequently complying freely with - the proposal that is implemented within their society's basic structure. (Thanks to Lori Watson for pressing me to clarify the motivation for this distinction.)
}

82 Political Utopias 
to their compliance with laws and institutions that they support. Alternatively, citizens may rationally decide against complying with laws and institutions that they think are justified if they lack assurance that others will do their part in terms of compliance. In such cases, though, insofar as citizens accept the justification(s) for the law or institution in question, and thus agree that their compliance is warranted, they will also accept (via instrumental reasoning) the use of those institutional mechanisms necessary to bring about and ensure their own compliance over time.$^{50}$ Here the enforcement of laws through the coercive power of the state plays a necessary role. The ongoing threat on the part of the state to exercise its coercive power to bring about general compliance with society's (justified) basic structure is a means by which citizens democratically can "bind" themselves to comply in the future with those laws that they find acceptable. The ongoing threat of coercive enforcement also helps assure citizens of the adequate compliance of others. ${ }^{51}$

Despite these nuances, I hold that it is part of the nature of a public reason justification that a successful justification-a justification that is acceptable to the reasonable persons to whom it is addressed-will motivate compliance. And this is the case whether the society in which those public reason justifications are advanced is well ordered or not. This is because a reasonable citizen cannot both (a) find a public reason justification for a law acceptable, and (b) be unwilling to comply freely (ceteris paribus) with that law. To affirm both (a) and (b) reveals a citizen to not be committed to reciprocity in her relations with others, and hence to be unreasonable. Thus public reason justifications, as they are addressed to reasonable citizens, involve at least local ideal theorizing.

So public reason justifications for political proposals cannot be severed from local ideal theorizing. What is the relation between local ideal theorizing and full ideal theorizing? How might citizens go from evaluating particular political proposals supported by public reason justifications to evaluating entire basic structures? Here is my suggestion. Some citizens endorse multiple political proposals. Such citizens judge their basic structure to be in need of wide-ranging reform. And each of these proposals aims at being acceptable to other citizens by means of public reason justifications; hence each of these proposals involve local ideal theorizing. Yet the proposals also should be mutually realizable, that is, citizens who endorse multiple political proposals for

\footnotetext{
${ }^{50}$ If the "costs" of such institutional mechanisms are quite high, though, reasonable citizens may reconsider their acceptance/endorsement of the laws or institutions in question. (Such possibilities do not affect my overall point here.)

${ }^{51}$ The threat of the coercive enforcement of laws would need to remain in place even within a wellordered society as a means for overcoming the assurance problem faced by individuals regarding their cooperation. (See Rawls 1999, 237-38, 277, 296, 305-6.) Given citizens' effective sense of justice, though, legal coercion would be exercised far less frequently within a well-ordered society than within non-well-ordered societies.
} 
their basic structure should do what they can to ensure that their various proposals, should they be implemented, do not undermine or conflict with each other. ${ }^{52}$ It makes little sense, I think, for citizens to aim at political proposals $\mathrm{x}, \mathrm{y}$, and $\mathrm{z}$, if $\mathrm{x}$ undermines or conflicts with $\mathrm{y}, \mathrm{y}$ undermines or conflicts with $\mathrm{z}$, and $\mathrm{x}$ undermines or conflicts with $\mathrm{z} .{ }^{53}$ In other words, a desideratum, if not a criterion, of a set of political proposals is that they all be (at least) mutually realizable..$^{54}$

At the limit, in offering a wide range of significant political proposals, all of which aim at acceptance by, and thereby compliance on the part of, other reasonable citizens, citizens end up describing a realistically utopian version of their society. More precisely, through the process of determining how their various political proposals fit together and can be supported adequately by public reason justifications, some citizens may find it necessary to engage in something like the standard version of Rawlsian ideal theorizing. According to the account sketched in this section, though, such ideal theorizing can begin with a concern with political reform that can be justified, in accordance with the principle of equal civic respect, to other reasonable citizens under existing non-ideal circumstances.

What I have proposed in this section is a way to understand the relation between public reasoning and ideal theorizing that is an alternative to the standard account. One reason why Anderson is critical of the standard account of the role of ideal theory in political philosophy (independent of the criticism that I discussed in the first section) is that she interprets ideal theorizing as adopting a perspective outside of or external to the political practices that it evaluates. "In ideal theory, ideals function as standards of assessment for any society," she writes. "They are not subject to testing in practice because they set standards, outside of practice, for the success of practice." 55 This way of understanding ideal theory construes the idea of a just well-ordered society as a kind of "Platonic form," one that transcends existing political societies, but which is meant to serve as a standard against which citizens can evaluate such societies. ${ }^{56}$ In contrast to this approach, Anderson describes her "non-ideal"

${ }^{52}$ Citizens may find acceptable incompatible political proposals as alternatives, but in doing so they of course acknowledge that only one of these alternatives can be realized within their basic structure. ${ }^{53}$ It would be rational, however, for citizens to promote political proposals $\mathrm{x}, \mathrm{y}$, and $\mathrm{z}$, even if those proposals conflict with or undermine each other, if the citizens in question believe that (a) only one (at most) of those proposals has a chance of being implemented, (b) the implementation of any one of those proposals would improve the overall justice of their society, and (c) they do not know which one (at most) of $\mathrm{x}, \mathrm{y}$, or $\mathrm{z}$ will (possibly) be implemented. I leave such unusual cases aside for present purposes.

${ }^{54}$ It also may be desirable that the proposals support or reinforce each other. Here I focus on the weaker claim that they should at least be mutually realizable.

${ }_{55}^{5}$ Anderson 2010, 6. See also Anderson 2009, 135.

${ }^{56}$ Sen refers to this way of thinking about justice as the "transcendental approach" and "transcendental institutionalism" (Sen 2006, 2009).

\footnotetext{
84 Political Utopias
} 
methodology for thinking about questions of political justice and injustice as beginning with the identification of a significant problem or set of problems with our existing political practices. She writes, "Nonideal theory begins with a diagnosis of the problems and complaints of our society and investigates how to overcome these problems." ${ }^{57}$ The account of the relation between public reasoning and ideal theorizing outlined in this section, however, employs the same starting point as that recommended by Anderson. Ideal theorizing can emerge out of citizens' attempts to address pressing political problems that they identify within their existing basic structure.

Moreover, given that Anderson endorses (a version of) the criterion of reciprocity, I do not think that her approach to theorizing about justice and injustice can be thoroughly "non-ideal" in nature. She writes, "[D]emocratic equality regards two people as equal when each accepts the obligation to justify their actions by principles acceptable to the other, and in which they take mutual consultation, reciprocation, and recognition for granted." ${ }^{8}$ So political proposals that aim at addressing existing injustices must employ justifications that satisfy the criterion of reciprocity. This means that Anderson's approach to theorizing about how to address specific forms of injustice must involve (at least) local ideal theorizing. This is because, as I have explained in this section, a consequence of a commitment to satisfying the criterion of reciprocity when advancing political proposals is a commitment to evaluating those proposals in light of compliance with them by citizens who find acceptable those proposals' justifications. In short, the alternative account of the relation between public reasoning and ideal theorizing that I have outlined in this section is not vulnerable to Anderson's criticism, and, furthermore, Anderson's own account of political justification commits her to (some role for) local ideal theorizing as part of the process of reasonable citizens justifying political proposals to one another..$^{59}$

3

In this section I provide a brief sketch of how I see the account outlined in the second section working in practice. This sketch draws upon some recent work on political and economic inequality in the contemporary United States.

\footnotetext{
${ }^{57}$ Anderson 2010, 6. Anderson draws an analogy between the role of political philosophy and the practice of medicine; the aim in both cases is to cure specific problems (Anderson 2009, 135; 2010, 3-4).

${ }^{58}$ Anderson 1999, 13 (my italics).

${ }^{59}$ I think that this point also can be pressed (mutatis mutandis) against other theorists who endorse (some version of) the criterion of reciprocity with respect to political justification but reject ideal theory. (I briefly discuss Gaus's account of political justification at the end of the next section.)
} 
AU: "a guarantee of employment for all citizens, ensuring universal heath care for citizens" As meant? Or "health care". Please clarify here and in note 66 (p. 26)

First, citizens reflect critically upon their circumstances, the basic structure in which they find themselves. In the case of the United States, they might conclude, with Rawls, that its basic structure manifests a number of features incompatible with the ideal of democratic equality, understood as fair social cooperation among free and equal citizens in accordance with the principle of civic respect. For instance, wealthy citizens have exercised, and increasingly exercise, highly disproportionate influence within the American political system. ${ }^{60}$ Moreover, this influence has altered the basic structure of the United States in ways that have dramatically increased economic inequality over the past four decades. ${ }^{61}$ Not only is this growing inequality economically damaging to society overall, ${ }^{62}$ but it has not improved the absolute incomes of the "least advantaged" within the United States during this period, that is, there has been no noteworthy "trickle-down" of economic benefit to the least advantaged. ${ }^{63}$ Moreover, recent research on the intergenerational elasticity of citizens' incomes suggests "that the United States is very immobile," and thus falls far short of realizing anything like a principle of equality of opportunity. ${ }^{64}$ And despite important changes to the legal structure of society over the past five decades, profound race-based and gender-based inequalities in income and wealth, economic opportunities, and political influence continue to persist.

In response to these features of their society, citizens committed to the ideal of democratic equality and the principle of equal civic respect might propose changes to their basic structure. Such changes might include, inter alia, public financing of election campaigns, reforms to the provision of basic education and the distribution of higher education (so that the distribution of education counteracts, rather than reinforces, existing class- and race-based inequalities ${ }^{65}$ ), a guarantee of employment for all citizens, ensuring universal heath care for citizens, ${ }^{66}$ and limiting the total amount of wealth that citizens can inherit in order to counteract the intergenerational concentration of wealth within a small portion of the population. ${ }^{67}$ Measures that aim at promoting

\footnotetext{
${ }^{60}$ See Gilens and Page 2014.

${ }^{61}$ See Hacker and Pierson 2010. On the overall increase in income inequality within the United States in recent decades, see Congressional Budget Office 2009, 2011.

${ }^{62}$ On the economic harms of high levels of inequality in income and wealth, see Stiglitz 2012; Galbraith 2014.

${ }^{63}$ The main reason for this, according to Lane Kenworthy (2010), has been government policy decisions.

${ }^{64}$ Mitnik and Grusky 2015, 4. See also Isaacs, Sawhill, and Haskins 2008; Pew Charitable Trusts 2012

${ }^{65}$ Among such educational reforms would be those that promote racial integration (see Anderson 2010).

${ }^{66}$ The proposals concerning campaign financing, employment, and heath care are mentioned in Rawls 2005, xlvi-xlvii.

${ }^{67}$ On the importance of minimizing the intergenerational accumulation of wealth within a small number of citizens, and the consequent role of taxing bequeathments and gifts, see Rawls 1999, 245-46; 2001, 160-61. Thomas Piketty (2014) recently has documented the long-term tendency of
} 
greater racial ${ }^{68}$ and gender equality ${ }^{69}$ within society also can be justified as necessary for securing the freedom and equality of all.

In advancing these kinds of political proposals, citizens aim at securing other reasonable citizens' acceptance of — and, if implemented democratically, willing compliance with-them by providing mutually acceptable justifications. But in formulating such proposals, and in trying to justify them, citizens might also try to determine how, and indeed whether, the proposals and their justifications fit together. In other words, citizens might ask, Can these proposals be justified and organized via coherent and compelling underlying principles that, in turn, express or are based upon the ideal of democratic equality and the principle of civic respect? This process of justification, reflection, and revision naturally may lead some citizens to identify what they take to be the most reasonable political conception of justice, the conception that, overall, they think best expresses the ideals of free and equal citizenship, and of fair social cooperation. And part of this process can include, for those citizens, trying to think about what their society would look like should all of their main political proposals be realized. Consequently, beginning with critical reflection on the injustices that citizens identify with their basic structure, and coming up with political proposals for addressing those injustices in a manner compatible with the principle of civic respect, some citizens may find themselves eventually trying to ascertain what a well-ordered society, a realistically utopian version of their society, would look like. Moreover, pressure toward thinking about a realistically utopian version of their society will be felt especially acutely by

capitalist societies toward what he terms "patrimonial capitalism." A patrimonial capitalist society, roughly, is one in which the members of that society's economic elite enjoy their privileged position primarily as a consequence of inheritance, not innovation or entrepreneurship. Simplifying greatly, the reason for this tendency is that returns to capital ("r") generally grow at a higher rate than the overall economy ("g"). Consequently, the already wealthy within society tend to become wealthier at a much faster rate than anyone else, and, moreover, pass this advantage on to their descendants. This economic elite becomes largely a class of rentiers. The members of this class also are able to employ their wealth to influence the political decision-making processes of their society, thereby undermining the democratic equality of citizens. Piketty's research appears to support Rawls's more speculative worries about the long-term tendency of capitalist societies toward growing inequality, decreasing political freedom for most citizens, and hence injustice. (For a discussion of the relevance of Piketty's work for Rawls's conception of justice as fairness and the idea of a "property-owning democracy," see Thomas 2015. For helpful discussion of Piketty's book, see DeLong 2014; Grewal 2014; Krugman 2014; Milanovic 2014; Solow 2014.)

${ }^{68}$ On extending Rawls's account of justice to address racial inequality, see Shelby 2004. Charles Mills has criticized Rawlsian ideal theory as incapable of addressing adequately issues of racial inequality (see Mills 2005, 2009), as well as Shelby's use of Rawls's theory (Mills 2013). For Shelby's reply to Mills, including his account of the role of ideal theory in thinking about racial injustice, see Shelby 2013. (The account of ideal theory that I advance here is, I think, broadly compatible with Shelby's position.)

${ }^{69}$ For public reason justifications for laws and policies that promote gender equality, see Baehr 2008; Brettschneider 2007; Hartley and Watson 2010; Lloyd 1998; Neufeld 2009; Neufeld and Van Schoelandt 2014. 
those citizens who agree with Rawls that the basic structure of their society is an interdependent system of social institutions. ${ }^{70}$ This is one reason why Rawls finds it necessary to outline the general features of a "property-owning democracy," ${ }^{11}$ a form of society that he thinks is both feasible and can realize successfully the ideal of free and equal citizenship.

It must be emphasized that, when engaging in critical reflection and deliberation regarding citizens' shared political practices and how to reform themincluding appealing to principles of justice and the idea of a realistic utopia in recommending changes to their basic structure-political philosophers occupy no privileged position. "[T]here are no philosophical experts," Rawls writes. "Heaven forbid!" 72 To claim otherwise would violate the principle of equal civic respect, the very principle that motivates reasonable citizens' commitment to public reasoning in the first place. And some, perhaps even most, citizens may be content simply to justify their political proposals in a piecemeal fashion, though in doing so they still aim at providing mutually acceptable justifications for those proposals - and thus aim at securing the free compliance of their fellow reasonable citizens with respect to those proposals (should they become part of their society's basic structure). Nonetheless, other citizens, especially those concerned with the overall coherence of their positions, should be free to propose changes to their basic structure by drawing upon the political conception of justice that they judge to be the most reasonable.

To illuminate this claim, consider the approach to public reason justifications recommend by Gerald Gaus. His "Public Justification Principle" states, " $L$ is a justified coercive law only if each and every member of the public $P$ has conclusive reason(s) $R$ to accept $L$ as binding on all." 73 The "conclusive reason(s)" in question need not draw upon a fully worked out conception of justice. Indeed, it is possible that the various laws that a given reasonable citizen ("member of the public") thinks are justified may be in tension with each other, or not share any

\footnotetext{
70 "The basic structure is understood as the way in which the major social institutions fit together into one system, and how they assign fundamental rights and duties and shape the division of advantages that arises through social cooperation" (Rawls 2005, 258; my italics).

${ }^{71}$ For Rawls's discussion of five different "ideal types" of socio-economic systems ("laissez-faire capitalism," "state socialism," "welfare-state capitalism," "liberal-democratic socialism," and "property-owning democracy"), see Rawls 2001, $\S 41-42,49$. Further discussion of the idea of a property-owning democracy can be found in Krouse and McPherson 1988; O’Neill and Williamson 2012; and Thomas 2015.

${ }^{72}$ Rawls 2005, 427. This is not to say, of course, that philosophers cannot contribute to the public political culture of democratic society: "citizens must, after all, have some ideas of right and justice in their thought and some basis for their reasoning. And students of philosophy take part in formulating these ideas but always as citizens among others" (my italics).

${ }^{73}$ Gaus 2010, 244. Gaus's Public Justification Principle does not require that citizens share any reason(s) for the law in question, though their different reasons should at least be mutually intelligible. In contrast, Rawls's account of public reason justifications holds that public reasons must be shareable among reasonable citizens (that is, be reasons that all reasonable citizens can accept). This difference between Gaus and Rawls is not relevant to my present discussion.
} 
coherent underlying principle(s). But if the account of public reasoning presented in the second section is plausible, then some citizens likely will try to ensure that the justifications for the various political proposals that they endorse are coherent. And in doing so, such citizens may come to draw upon a reasonable political conception of justice that applies to the overall basic structure of their society. ${ }^{74}$ As far as I can tell, nothing in Gaus's account of political justification bars citizens from doing this, and indeed it would be a serious mark against his view if citizens could not draw upon a full political conception of justice when justifying their particular political proposals. ${ }^{75}$ So even if one endorses Gaus's account of public reason justifications, which rests upon (a version of) the criterion of reciprocity, those citizens who care about the overall coherence of their political proposals may find it necessary to engage in full ideal theorizing, that is, they may outline and draw upon their conception of a realistically utopian version of their society. ${ }^{76}$ Such "Rawlsians," after all, are "members of the public" too!"7

In this paper I outlined a new way to construe the relation between public reasoning and ideal theorizing. My account rests upon the claim that we can understand the

\footnotetext{
${ }^{74}$ Such citizens may understand the basic structure as an interdependent system of laws and institutions (see n. 70). Gaus notes that, for many citizens, whether a particular political proposal is justified will depend upon what other laws or policies are in place or will be implemented along with that proposal. In such cases of "justificatory dependency," issues $x$ and $y$ are interdependent if there is at least one reasonable citizen (member of the public) who cannot rank proposals concerning $x$ independently of laws and policies concerning $y$ (see Gaus 2011, 495f.). As Andrew Lister notes, the criterion of justificatory dependency seems to introduce a high degree of "holism" into Gaus's account of public justification (see Lister 2013a).

${ }^{75}$ However, Gaus does object to Rawls's use of the original position device in order to yield a determinate set of political principles, namely, the conception of justice as fairness. This move fails to respect the evaluative diversity characteristic of contemporary pluralist societies, Gaus maintains, including diversity in citizens' political views. Rawls's original position, Gaus writes, "entirely does away with the idea of pluralistic reasoning" (Gaus 2011, 284; see also Gaus 2010, 248-49, 274.) This interpretation of the role of the original position in Rawls's political philosophy is incorrect. The original position is a philosophical device by means of which citizens can explain why they are committed to the conception of justice as fairness, and thus endorse the political proposals that they think follow from that conception. But it is only one way, not the only way, for citizens to satisfy the criterion of reciprocity (see Rawls 2005, xlviii-xlix). And when citizens defend their political positions by drawing upon a political conception of justice that is specified via the original position, they do so as free and equal members of the public, not as privileged philosophical experts (see n. 72). Since nothing in Rawlsian political liberalism requires the use of the original position in order to justify political conceptions of justice, the use of the original position by some citizens to justify their political positions in no way "does away with the idea of pluralistic reasoning."

${ }^{76}$ And, if the argument in the second section is successful, justifying particular political proposals in compliance with the Public Justification Principle involves (at least) local ideal theorizing.

${ }^{77}$ And so are "Hayekians," for that matter. Hayek employs a method for assessing "different order[s] of society" that is very similar to Rawls's original position (Hayek 1976, 132). (For a helpful discussion of the "Rawlsian" nature of many of Hayek's views, see Lister 2013b.)
} 
idea of public reason as based upon the principle of equal civic respect. In order to satisfy this principle, justifications for political proposals should be capable of securing the acceptance — and, by means of that acceptance, the compliance- of those reasonable citizens to whom they are addressed. Consequently, a role for the idea of full compliance cannot be severed from public reason justifications even when deployed by citizens within non-well-ordered societies. If I am right about this, then theorists like Anderson, Gaus, and Sen are mistaken in holding that a commitment to public reason justifications - understood broadly to involve the satisfaction of (some version of) the criterion of reciprocity-for political proposals need not involve any form of ideal theorizing. Public reason justifications for political proposals involve at least local ideal theorizing.

I also tried to provide an account of how public reason justifications can come to appeal to the idea of a well-ordered society. On my account, the idea of a realistic utopia of a fully just, well-ordered society need not constitute a kind of "external" standard by means of which citizens should (or must) orient their thinking about justice. Rather, those citizens concerned with the overall coherence of their political proposals may find it helpful to try to ascertain what their society would look like should their public reason justifications for those proposals be accepted by their fellow citizens, and consequently their proposals be realized within their society's basic structure. Ideal theorizing may even be necessary for those citizens who identify especially deep or widespread injustices within their existing political practices.

The alternative account of the relation between public reasoning and ideal theorizing that I outlined in the second and third sections is compatible with the standard Rawlsian view of this relation (as summarized in the first section). This is because the conclusions of the standard account and those of my alternative account both can be affirmed by public reasoners. My approach holds that even if we begin by formulating political proposals to address problems within existing non-ideal circumstances, a commitment to the principle of equal civic respect involves local ideal theorizing, and this, in turn, can lead citizens to engage in full ideal theorizing. The outcomes of this process need not differ, though, from those generated by the standard account, according to which citizens begin with ideal theorizing and then consider political questions in non-ideal circumstances. Both approaches may lead reasonable citizens ultimately to endorse the political conception of justice as fairness and its prescriptions for contemporary capitalist societies. ${ }^{78}$

${ }^{78}$ Earlier versions of this paper were presented at the Bowling Green State University's philosophy workshop on "Political Utopia: Promise or Peril?" (April 2014) and the Association for Political Theory's annual meeting at the University of Wisconsin-Madison (October 2014). I am grateful to the members of the audiences at those presentations for their helpful comments and criticisms. For reading and commenting upon earlier versions of this paper, I would like to thank Sonu S. Bedi, Jeffrey M. Carroll, Andrew J. Cohen, Julian Culp, Christie Hartley, Andrew Lister, Chad Van Schoelandt, Philip Smolenski, Lori Watson, and two anonymous referees.

90 Political Utopias 


\section{References}

Anderson, Elizabeth. 1999. "What is the Point of Equality?" Ethics 109: 287-337.

Anderson, Elizabeth. 2009. "Toward a Non-Ideal, Relational Methodology for Political Philosophy: Comments on Schwartzman's Challenging Liberalism." Hypatia 24: $130-45$.

Anderson, Elizabeth. 2010. The Imperative of Integration. Princeton, NJ: Princeton University Press.

Anderson, Elizabeth. 2012. "The Fundamental Disagreement between Luck Egalitarians and Relational Egalitarians." Canadian Journal of Philosophy, supplementary vol. 36: $1-23$.

Baehr, Amy. 2008. "Perfectionism, Feminism, and Public Reason." Law and Philosophy 27: 193-222.

Brettschneider, Corey. 2007. "The Politics of the Personal: A Liberal Approach." American Political Science Review 101: 19-31.

Boettcher, James. 2007. "Respect, Recognition, and Public Reason." Social Theory and Practice 33: 223-49.

Congressional Budget Office. 2009. "Data on the Distribution of Federal Taxes and Household Income."

Congressional Budget Office. 2011. "Trends in the Distribution of Household Income between 1979 and 2007."

Darwall, Stephen. 1995. "Two Kinds of Respect." In Dignity, Character, and SelfRespect, edited by R. S. Dillon, 181-97. New York: Routledge.

Darwall, Stephen. 2006. The Second-Person Standpoint. Cambridge, MA: Harvard University Press.

DeLong, Bradford. 2014. "Mr. Piketty and the 'Neo-classicists': A Suggested Interpretation." Grasping Reality (blog), August 20. http://delong.typepad.com/

\begin{tabular}{|c|}
\hline AU: In \\
reference \\
"Anderson, \\
Elizabeth. \\
2012" \\
does the \\
supplement \\
have its own \\
title? If so, \\
format as \\
per Chicago \\
14.188. (p. \\
35) \\
\hline
\end{tabular}

AU: Please provide information, like URL or place of publication for

Congressiona Budget

Office. 2009 \& 2011 if possible (p. 35) delong_long_form/2014/05/the-honest-broker-mr-piketty-and-the-neoclassicists-asuggested-interpretation-for-the-week-of-may-17-2014.html.

Galbraith, James. K. 2014. The End of Normal: The Great Crisis and the Future of Growth. New York: Simon \& Schuster.

Gaus, Gerald. 2010. "Coercion, Ownership, and the Redistributive State: Justificatory Liberalism's Classical Tilt.” Social Philosophy and Policy 27: 233-75.

Gaus, Gerald. 2011. The Order of Public Reason: A Theory of Freedom and Morality in a Diverse and Bounded World. New York: Cambridge University Press.

Gaus, Gerald, and Kevin Vallier. 2009. "The Roles of Religious Conviction in a Publicly Justified Polity: The Implications of Convergence, Asymmetry, and Political Institutions." Philosophy and Social Criticism 35: 51-76.

Gilens, Martin, and Benjamin I. Page. 2014. "Testing Theories of American Politics: Elites, Interest Groups, and Average Citizens.” Perspectives on Politics 12: 564-81.

Grewal, David S. 2014. "The Laws of Capital: Review of Thomas Piketty, Capital in the Twenty-First Century." Harvard Law Review 128: 626-67.

Hacker, Jacob S., and Paul Pierson. 2010. Winner-Take-All Politics. New York: Simon and Schuster.

Hadfield, Gillian K., and Stephen Macedo. 2012. "Rational Reasonableness: Toward a Positive Theory of Public Reason." Law \& Ethics of Human Rights 6: 6-46.

WHY PUBLIC REASONING INVOLVES IDEAL THEORIZING 91 
Hartley, Christie, and Lori Watson. 2010. "Is a Feminist Political Liberalism Possible?" Journal of Ethics and Social Philosophy 5: 37-54.

Hayek, Friedrich A. 1976. The Mirage of Social Justice. Vol. 2 of Law, Legislation and Liberty. Chicago: University of Chicago Press.

Isaacs, Julia B., Isabel V. Sawhill, and Ron Haskins. 2008. Getting Ahead or Losing Ground: Economic Mobility in America. The Economic Mobility Project, the Brookings Institution and the Pew Charitable Trusts. https://www.brookings.edu/wpcontent/uploads/2016/06/02_economic_mobility_sawhill.pdf.

Kenworthy, Lane. 2010. "Rising Inequality, Public Policy, and America's Poor." Challenge 53: 93-109.

Krouse, Richard, and Michael McPherson. 1988. "Capitalism, 'Property-Owning Democracy,' and the Welfare State.” In Democracy and the Welfare State, edited by A. Gutmann, 79-105. Princeton, NJ: Princeton University Press.

Krugman, Paul. 2014. "Why We're in a New Gilded Age." New York Review of Books, May 8. http://www.nybooks.com/articles/2014/05/08/thomas-piketty-new-gilded-age/.

Larmore, Charles. 1999. “The Moral Basis of Political Liberalism.” Journal of Philosophy 96: 599-625.

Lister, Andrew. 2013a. “The Classical Tilt of Justificatory Liberalism.” European Journal of Political Theory 12 (3): 316-26.

Lister, Andrew. 2013b. "The Mirage of Social Justice: Hayek Against (and For) Rawls." Critical Review 25 (3-4): 409-44.

Lloyd, Sharon A. 1998. "Toward a Liberal Theory of Sexual Equality." Journal of Contemporary Legal Issues 9: 203-24.

Milanovic, Branko. 2014. "The Return of 'Patrimonial Capitalism': A Review of Thomas Piketty's Capital in the Twenty-First Century." Journal of Economic Literature 52 (2): 519-34.

Mills, Charles. 2005. “'Ideal Theory’ as Ideology.” Hypatia 20: 165-84.

Mills, Charles. 2009. "Rawls on Race/Race in Rawls.” In "Race, Racism, and Liberalism in the Twenty-First Century," edited by B. E. Lawson, supplement, Southern Journal of Philosophy 47: 161-84.

Mills, Charles. 2013. "Retrieving Rawls for Racial Justice? A Critique of Tommie Shelby." Critical Philosophy of Race 1: 1-27.

Mitnik, Pablo A., and David B. Grusky. 2015. Economic Mobility in the United States. The Pew Charitable Trusts and the Russell Sage Foundation. http://www.pewtrusts. org/ /media/assets/2015/07/fsm-irs-report_artfinal.pdf.

Neufeld, Blain. 2005. "Civic Respect, Political Liberalism, and Non-Liberal Societies." Politics, Philosophy \& Economics 4: 275-99.

Neufeld, Blain. 2009. "Coercion, the Basic Structure, and the Family.” Journal of Social Philosophy 40: 37-54.

Neufeld, Blain, and Chad Van Schoelandt. 2014. "Political Liberalism, Ethos Justice, and Gender Equality." Law and Philosophy 33: 5-104.

Nussbaum, Martha. 2011. "Perfectionist Liberalism and Political Liberalism.” Philosophy \& Public Affairs 39: 3-45.

O’Neill, Martin. 2012. "Free (and Fair) Markets without Capitalism." In PropertyOwning Democracy: Rawls and Beyond, edited by M. O’Neill and T. Williamson, 75-100. Oxford: Wiley-Blackwell.

92 Political Utopias 
O’Neill, Martin, and Thad Williamson, eds. 2012. Property-Owning Democracy: Rawls and Beyond. Oxford: Wiley-Blackwell.

Pew Charitable Trusts. 2012. "Pursuing the American Dream: Economic Mobility Across Generations." Economic Mobility Project. http://www.pewtrusts.org/ /media/legacy/uploadedfiles/wwwpewtrustsorg/reports/economic_mobility/ pursuingamericandreampdf.pdf.

Piketty, Thomas. 2014. Capital in the Twenty-First Century. Cambridge, MA: Harvard University Press.

Rawls, John. (1971) 1999. A Theory of Justice. Cambridge, MA: Harvard University Press. All references are to the revised edition, 1999.

Rawls, John. (1993) 2005. Political Liberalism. New York: Columbia University Press. All references are to the expanded edition, 2005.

Rawls, John. 2001. Justice as Fairness: A Restatement. Cambridge, MA: Harvard University Press.

Sen, Amartya. 2006. "What Do We Want From A Theory of Justice?" The Journal of Philosophy 103: 215-38.

Sen, Amartya. 2009. The Idea of Justice. Cambridge, MA: Harvard University Press.

Shelby, Tommie. 2004. "Race and Social Justice: Rawlsian Considerations." Fordham Law Review 72: 1697-1714.

Shelby, Tommie. 2013. "Racial Realities and Corrective Justice: A Reply to Charles Mills." Critical Philosophy of Race 1: 146-62.

Simmons, John A. 2010. "Ideal and Nonideal Theory." Philosophy \& Public Affairs 38: 5-36.

Solow, Robert. 2014. "Piketty is Right: Review of Thomas Piketty, Capital in the TwentyFirst Century." The New Republic, April 22. http://www.newrepublic.com/article/ 117429/capital-twenty-first-century-thomaspiketty-reviewed.

Stiglitz, Joseph. 2012. The Price of Inequality: How Today's Divided Society Endangers Our Future. New York: W. W. Norton and Company, Inc.

Stemplowksa, Zofia, and Adam Swift. 2014. "Rawls on Ideal and Nonideal Theory." In A Companion to Rawls, edited by J. Mandle and D. A. Reidy, 112-27. Oxford: John Wiley \& Sons, Inc.

Thomas, Alan. 2015. "Rawls, Piketty, and the New Inequality." Unpublished manuscript.

Valentini, Laura. 2012. "Ideal vs. Non-ideal Theory: A Conceptual Map.” Philosophy Compass 7: 654-64.

Weithman, Paul. 2010. Why Political Liberalism? On John Rawls's Political Turn. New York: Oxford University Press. 